\begin{tabular}{|l|l|l||}
\hline \multicolumn{2}{|c|}{ PublisherInfo } \\
\hline \hline PublisherName & $:$ & BioMed Central \\
\hline \hline PublisherLocation & $:$ & London \\
\hline \hline PublisherImprintName & $:$ & BioMed Central \\
\hline \hline
\end{tabular}

\title{
Truncated BRCA2 is cytoplasmic
}

\begin{tabular}{|l|l|l||}
\hline \multicolumn{2}{|c||}{ ArticleInfo } \\
\hline \hline ArticleID & $:$ & 3684 \\
\hline \hline ArticleDOI & $:$ & $10.1186 /$ bcr-2000-66647 \\
\hline \hline ArticleCitationID & $:$ & 66647 \\
\hline \hline ArticleSequenceNumber & $:$ & 50 \\
\hline \hline ArticleCategory & $:$ & Paper Report \\
\hline \hline ArticleFirstPage & $:$ & 1 \\
\hline \hline ArticleLastPage & $:$ & 4 \\
\hline \hline & $:$ & RegistrationDate : 2000-1-5 \\
ArticleHistory & $:$ & OnlineDate \\
\hline \hline ArticleCopyright & $:$ & Current Science Ltd2000-5 \\
\hline \hline ArticleGrants & $:$ & \\
\hline \hline ArticleContext & $:$ & 1305822 \\
\hline \hline
\end{tabular}




\section{Keywords}

BRCA2 6174delT mutant, green fluorescent protein, nuclear localisation signal

\section{Introduction}

Germ-line mutations in the breast cancer susceptibility gene $B R C A 2$ predispose carriers to breast cancer. The vast majority of these mutations are predicted to lead to the production of a truncated BRCA2 protein, lacking the $\mathrm{C}$ terminus. Thus the $\mathrm{C}$ terminus of $\mathrm{BRCA} 2$ may contain an important functional domain.

\section{Aims}

To determine the biochemical function of the C-terminal region of BRCA2.

\section{Comments}

BRCA2 is localised to the nucleus and the functions ascribed to it are nuclear functions. This study identifies two nuclear localisation signals (NLSs) within BRCA2 and makes the important observation that they are downstream of all known cancer-associated truncating mutations in BRCA2. Therefore, truncated forms of BRCA2 may be non-functional due to an inability to translocate to the nucleus.

\section{Methods}

Immunofluorescence of 293T cells, transiently transfected with expression vectors for green fluorescent protein (GFP)-tagged $B R C A 2$ fragments. Western blots of nuclear and cytoplasmic fractions of BRCA2 mutant cells. 


\section{Results}

Sequence analysis of $B R C A 2$ revealed the presence of four potential nuclear localisation signals (NLSs), three near the C terminus. Immunofluorescence of 293T cells, transfected with plasmids expressing GFP-tagged BRCA2 fragments, suggests that the C terminus of BRCA2 is responsible for nuclear translocation.

A series of plasmids encoding GFP-tagged, C-terminal fragments of BRCA2 containing mutations in the different putative NLSs were used for further immunofluorescence studies. These experiments indicate that only two of the possible NLSs, consisting of amino acids 3263-3269 and 3381-3385, are functional.

The pancreatic cancer cell line Capan-1 only has the 6174delT mutant form of BRCA2, which expresses a truncated BRCA2 protein, lacking both functional NLSs. Immunofluorescence of 293T cells transfected with a plasmid expressing GFP-tagged, 6174delT BRCA2 indicates that this truncated BRCA2 protein is located in the cytoplasm. Western blots of fractions of Capan-1 cells revealed that the endogenous 6174delT BRCA2 protein is also localised to the cytoplasm.

\section{Discussion}

If the nuclear exclusion of truncated BRCA2 proteins is also observed in primary tumour samples, then individuals with truncating mutations in BRCA2could be screened by immunostaining.

Mice homozygous for some truncating mutations of Brca2suffer embryonic lethality. By contrast, some mice with other, more 3 ' truncating mutations survive to adulthood. These latter mice presumably produce a partially functional mutant $\mathrm{Brca} 2$ protein, yet this protein lacks the $\mathrm{C}$ terminus. It will therefore be interesting to see whether this mutant Brca2 protein localises to the nucleus.

RAD51, a nuclear protein, has been shown to interact with the 6174delT form of BRCA2, which lacks the NLSs and is localised to the cytoplasm. However, since this has been demonstrated by coimmunoprecipitation, the complex may form after lysis of the cells. 


\section{References}

1. Spain BH, Larson CJ, Shihabuddin LS, Gage FH, Verma IM: Truncated BRCA2 is cytoplasmic: Implications for cancer-linked mutations. Proc Natl Acad Sci USA. 2000, 96: 13920-13925.

This PDF file was created after publication. 